ISSN: 1979-7362

\title{
Daya Dukung Tanah Pada Lahan Sawah Siap Tanam
}

\author{
Suparding ${ }^{1}$, Suhardi ${ }^{1}$ dan Supratomo ${ }^{1}$ \\ ${ }^{1)}$ Program Studi Teknik Pertanian, Universitas Hasanuddin Makassar
}

\begin{abstract}
ABSTRAK
Daya dukung tanah merupakan daya yang dibutuhkan oleh tanah untuk menahan beban yang berada diatasnya. Daya dukung tanah sangat dipengaruhi oleh sifat-sifat tanah seperti kadar air tanah, berat isi, struktur, kelembaban, bahan organik tanah, dan tekstur tanah. Metode plat pembeban merupakan salah satu metode yang digunakan untuk mengetahui daya dukung tanah. Adapun tujuan dari penelitian ini yaitu untuk mengetahui daya dukung tanah pada lahan persawahan yang siap tanam dengan menggunakan plat pembeban. Tahapan dari penelitian ini yaitu pengujian daya dukung tanah menggunakan Plat besi pembebeban dengan luas permukaan $50 \mathrm{~cm}^{2}, 120 \mathrm{~cm}^{2}$, dan $150 \mathrm{~cm}^{2}$ dengan pemberat $1 \mathrm{~kg}, 2 \mathrm{~kg}$, dan 3 $\mathrm{kg}$. Dengan kadar air tanah $56,7 \%$ dan fraksi pasir $11 \%$ diperoleh hubungan antara daya dukung tanah $(\mathrm{y})$ dengan bobot pemberat $(\mathrm{x})$ adalah $\mathrm{y}=0,8592 \mathrm{x}$ dan daya dukung tanah $(\mathrm{y})$ dengan luas penampang alat $(\mathrm{x})$ adalah $\mathrm{y}=20,00 \mathrm{e}^{0,04 \mathrm{x}}$. Sedangkan daya dukung tanah $(\mathrm{y})$ pada kadar air 48,6\% dengan fraksi pasir $4 \%$ dengan luas penampang alat (x) menghasilkan rumus $\mathrm{y}=41,57 \mathrm{e}^{0,04 \mathrm{x}}$ dan daya dukung tanah $(\mathrm{y})$ dengan bobot pemberat $(\mathrm{x})$ menghasilkan rumus $\mathrm{y}=0,8592 \mathrm{x}$.
\end{abstract}

\section{Kata kunci: Plat Pembeban, Daya Dukung Tanah, Tekstur, Kadar Air Tanah}

\section{PENDAHULUAN}

\section{Latar Belakang}

Indonesia merupakan salah satu negara di dunia yang memiliki lahan pertanian yang begitu luas. Dimana luas lahan pertaniaannya mencapai 41,5 juta ha dan 8,1 juta ha lebih merupakan lahan persawahan. (Badan Pusat Statistika, 2014).

Kebutuhan akan pangan setiap tahunnya mengalami peningkatan khususnya beras, hal tersebut menuntut pemerintah untuk mengoptimalkan penggunaan lahan sawah guna meningkatkan kualitas dan jumlah produksi gabah kering atau beras. Seiring dengan perkembangan teknologi, alat atau mesin mulai di ciptakan untuk memenuhi kebutuhan dalam dunia pertanian khususnya persawahan. Pada umumnya lahan sawah di Indonesia dibuat dalam betuk petakan-petakan kecil, Kondisi lahan yang sempit tersebut menuntut agar adanya inovasi dalam penerapan teknologi. Dalam analisis perancangan alat pertanian khususnya alat-alat budidaya pertanian ada banyak faktor yang menjadi pertimbangan, salah satunya adalah faktor daya dukung tanah yang berkaitan langsung dengan perancangan roda dari alat yang hendak dirancang.

Pegujian daya dukung lebih banyak dilakukan pada lahan kering dan pada struktur tanah tidak terganggu. Pengujian daya dukung tanah pada lahan basah khususnya pada lahan persawahan masih sedikit karena dianggap tidak terlalu penting. Data-data tentang hasil pengujian daya dukung tanah pada lahan basah masih sangat jarang dan sulit ditemui. Data daya dukung tanah bukan hanya digunakan untuk mengetahui kemampuan tanah dalam meyediakan air dan kemampuan penetrasi akar tanaman. akan tetapi, juga dapat digunakan untuk mengetahui kemampuan tanah menahan alat atau mesin budidaya pertanian yang bekerja diatasnya.

Daya dukung tanah merupakandaya yang dibutuhkan oleh tanah untuk 
menahan beban yang berada diatasnya. Apabila suatu alat berada di atas tanah, maka alat tersebut akan memberikan ground pressure, sedangkan perlawanan yang diberikan tanah adalah "daya dukung”. Jika ground pressure alat lebih besar dari daya dukung tanah, maka alat tersebut akan terbenam. Daya dukung tanah sangat dipengaruhi oleh sifat-sifat tanah seperti air tanah, berat isi, struktur, kelembaban, bahan organik tanah, dan tekstur tanah. Nilai ketahanan tanah meningkat dengan menurunnya kelembapan tanah dan tekstur tanah. Pada kelembapan tanah rendah, ketahanan tanah meningkat, demikian juga dengan meningkatnya kandungan pasir. (Kurnia et al, 2006).

Daya dukung tanah dapat diketahui dengan beberapa metode yaitu dengan metode tradisional (menggunakan ibu jari), metode pemberat, atau dengan menggunakan alat yang lebih canggih yang biasa dikenal dengan penetrometer atau penetrograph. Penetrometer atau penetrograph merupakan alat yang digunakan untuk mengukur ketahanan tanah yang dimaksudkan untuk menilai kondisi tanah dalam hubungannya dengan pertumbuhan dan perkembangan akar di dalam tanah, hasil panen, dan sifat-sifat fisik tanah lainnya yang berhubungan dengan produksi pertanian. Dalam penggunaan penetrometer, sifat-sifat tanah dapat mempengaruhi daya dukung tanah. Metode pemberat merupakan salah satu metode pengujian daya sanggah atau dukung tanah yang memiliki keunggulan yaitu sangat mudah dalam penggunaannya, murah, dan merupakan model suatu alat yang dapat dirakit sendiri (Kurniaet al, 2006).

Berdasarkan dari uraian di atas, maka dipandang perlu untuk melakukan penelitian tentang pengujian daya dukung tanah pada lahan sawah siap tanam, data daya dukung tanah yang diperoleh kemudian dapat dijadikan data acuan untuk mendesain atau merancang mesin budidaya pada lahan basah

\section{Tujuan dan Kegunaan}

Penelitian ini bertujuan untuk mengetahui daya dukung tanah pada lahan persawahan yang siap tanam.

Kegunaan dari penelitian ini adalah dapat digunakan sebagai data acuan atau referensi dalam merencanakan pembuatan atau perancangan mesin-mesin budidaya pertanian yang berkaitan dengan kegiatan penanaman.

\section{METODOLOGI PENELITIAN}

\section{Waktu dan Tempat}

Penelitian daya dukung tanah pada lahan sawah siap tanam akan dilaksanakan mulai pada bulan Maret 2017, pada dua lokasi berbeda (Kecamatan Simbang dan Kecamatan Tanralili) di Kabupaten Maros, Provinsi Sulawesi Selatan.

\section{Alat dan Bahan}

Alat yang digunakan ada penelitian ini adalah Plat besi baja dengan luas penampang $50 \mathrm{~cm}^{2}, 120 \mathrm{~cm}^{2}$, dan $150 \mathrm{~cm}^{2}$, pemberat $(1 \mathrm{~kg}, 2 \mathrm{~kg}$ dan $3 \mathrm{~kg})$, kamera, stopwatch, laptop, mistar, plastik sampel dan bolpain.

Bahan yang digunakan pada penelitian ini adalah buku catatan, sampel tanah yang diperoleh dari lahan sawah, dan kertas label.

\section{Metode Penelitian}

Persamaan $P=F /$ A di hitung dengan menentukan nilai v, a, $F$ dan A, dimana nilai tersebut dapat ditentukan melalui tahapan-tahapan yang ada pada prosedur kerja 3.3.1. Pengambilan Data Lapangan. Prosedur penelitian uji daya dukung tanah pada lahan sawah siap tanam dilakukan dengan cara sebagai berikut:

a. Pengambilan Data Lapangan

1. Menentukan lahan sawah yang telah diolah (siap tanam) yang akan diuji ketahanan tanahnya. 
2. Menyiapkan dua macam plat dengan luas penampang yang berbeda (50 $\mathrm{cm}^{2}, 120 \mathrm{~cm}^{2}$, dan $150 \mathrm{~cm}^{2}$ ).

3. Mengukur berat beban pada masingmasing plat

4. Menempatkan alat diatas permukaan tanah pada lahan yang rata bersamaan dengan mengaktifkan stopwatch

5. Catat waktu tenggelam alat (pada stopwatch) sampai alat tidak mampu lagi melakukan penetrasi dan kedalaman tenggelam alat (dengan melihat meteran yang dipasang pada dinding alat) sampai alat tidak mampu lagi melakukan penetrasi.

6. Ganti alat dengan lebar penampang yang berbeda. Kemudian, ulangi langkah 4 sampai 6

7. Mengambil sampel tanah dalam keadaan basah pada lahan sawah sebanyak 200 gram menggunakan plastik sampel.

8. Mengambil gambar kondisi lahan

9. Menghitung kecepatan tenggelam alat dengan rumus :

$\operatorname{Kecepatan}(\mathrm{v})=\frac{\text { Jarak tempuh }(\mathrm{s})}{\text { Waktu tempuh( }(\mathrm{t})}$

10. Menghitung daya sanggah tanah dengan rumus : $P=F / A$

b. Penentuan Tekstur Tanah di Laboratorium

1. Membawa sampel tanah kelaboratorium untuk di tentukan teksturnya.

2. Timbang 25 gram contoh tanah kering udara dengan ayakan $2 \mathrm{~mm}$ kedalam botol tekstur.

3. Tambahkan $10 \mathrm{ml}$ larutan pendispersi natrium pirosposfat.

4. Tambahkan air sampai $200 \mathrm{ml}$

5. Kocok dengan mesin pengocok/mixer selama 5 menit.

6. Tuangkan secara kualitatif semua isisnya kedalam silinder sedimentasi $500 \mathrm{ml}$ yang diatasnya dipasang saringan dengan diameter lubang sebesar $0.05 \mathrm{~mm}$.
7. Semprot dengan botol semprot sambil aduk-aduk semua suspensi yang masih tinggal pada saringan sehingga semua partikel debu dan liat telah turun ( air saringan telah jernih).

8. Pindahkan pasir yang tertinggal kedalam cawan petri dengan botol semprot kemudian ovenkan hingga kering.

9. Masukkan dalam desikator dan timbang berat pasir ( $\mathrm{C}$ gram).

10. Encerkan larutan suspensi dalam silinder sedimentasi dengan air destilasi hingga $500 \mathrm{ml}$.

11. Kocok suspensi dengan pengocok khusus selam 30 detik.

12. Setelah 15 detik, masukkan hydrometer dan termometer ke dalam suspensi, diamkan dan setelah 40 detik baca dan catat pembacaan hydrometer pertama (H1) dan suhi suspensi (T1).

13. Keluarkan hydrometer dengan hatihati.

14. Setelah 8 jam, masukkan hydrometer dan termometer, catat pembacaan hydrometer kedua (H2) dan suhu suspensi (T2).

15. Menghitung persen pasir dengan:

a. (bacaan terkoreksi pada 40 detik/tanah kering oven) $\times 100=$ $\%$ liat dan debu.

b. $100-(\%$ liat dan debu $)=\%$ pasir.

16. Menghitung persen liat $=$ (bacaan terkoreksi pada 1 jam/tanah kering oven) $\times 100=\%$ liat

17. Menghitung persen debu $=100-$ (\% pasir - \% liat) x \% debu.

18. Setelah persen pasir, liat dan debu diketahui, gunakan gambar segitiga tekstur unutk menentukan kelas tekstur tanah.

c. Pengukuran Kadar Air Tanah di Laboratorium

1. Membawa sampel tanah basah ke Laboratorium untuk di uji kadar airnya. 
2. Menimbang cawan petridish, kemudian menambahkan 100 gram sampel tanah kering udara tersebut kedalam cawan petridish.

3. Mengeringkan di dalam oven dengan suhu $105^{\circ} \mathrm{C}-110^{\circ} \mathrm{C}$ selama $24 \mathrm{jam}$.

4. Mengeluarkan cawan petridish dan tanah dari oven, mendinginkan dalam desikator kemudian menimbang cawan petridish bersama tanah.

5. Menghitung dengan menggunakan rumus:

Berat cawng petridis $=$ a gram

Berat cawang petridis + tanah kering udara $=\mathrm{b}$ gram

Berat cawang petridis + tanah kering oven $=\mathrm{c}$ gram

6. Menghitung berat tanah kering udara $=(b-a)$

7. Menghitung berat tanah kering oven $=(\mathrm{c}-\mathrm{a})$

8. Menghitung Berat air yang hilang = (b-c)

9. Menghitung kandungan air tanah dengan rumus:

$$
\frac{(b-a)-(c-a)}{(c-a)} \times 100 \%
$$

\section{Analisis Data}

1. Menganalisis Perbandingan Luas Penampang Alat dengan Kecepatan Tenggelam Alat

2. Menganalisis Perbandingan berat alat dengan kecepatan tenggelam alat berdasarkan luas penampag.

3. Menganalisis hubungan berat alat, luas penampang alat, dengan kecepatan tenggelam alat.

4. Menganalisis hubungan daya dukung tanah dengan berat alat.

5. Menganalisis hubungan daya dukung tanah dengan luas penampang alat.

6. Menganalisis hubungan berat alat, luas penampang alat, dengan waktu tenggelam alat.

7. Menganalisis hubungan berat alat, luas penampang alat, dengan persentase tenggelam alat.

\section{Bagan Alir Penelitian}

Penelitian ini dilakukan dengan bagan alur sebagai berikut:

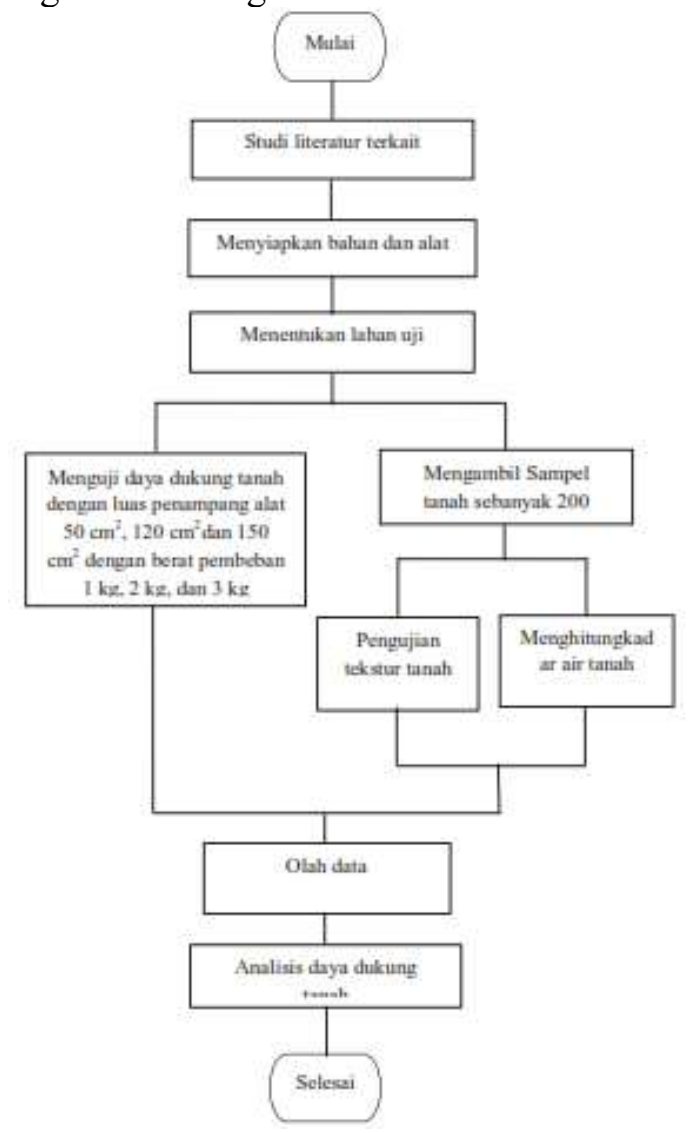

Gambar 1. Bagan alir penelitian

\section{HASIL DAN PEMBAHASAN}

\section{Keadaan Umum Lokasi Penelitian}

Penelitian tentang daya dukung tanah pada lahan sawah siap tanam dilakukan di Kecamatan Simbang dan Kecamatan Tantralili, Kabupaten maros. Kecamatan Simbang terletak di Desa Je'netaesa yang memiliki luas wilayah $105,31 \mathrm{~km}^{2}$ dengan koordinat Geografis berada pada $5^{0} 1$ ' 29' ' LS dan $119^{0} 39^{\prime} 48$ BT. Kecamatan Simbang yang keadaan wilayahnya terdiri dari daaran rendah yang dilintasi kawasan pegunungan karst, sehingga sangat cocok dikembangkan untuk lahan persawahan. Sedankang Kecamatan Tanralili secara geografis terletak diantara $119^{0} 34^{\prime} 11,9^{\prime}$ ' - $119^{0} 40^{\prime}$ $48^{\prime \prime}$ 'BT dan 50 2'59,9' - 5 $5^{0} 10^{\prime} 47,9$ ' LS 
dengan luas wilayah 89,46 $\mathrm{km}^{2}$ (BPS Kabupaten Maros, 2013).

Kabupaten Maros termasuk daerah yang beriklim tropis, karena letaknya yang berada pada daerah khatulistiwa dengan kelembaban berkisar antara $60 \%-82 \%$ .Curah hujan tahunan rata - rata 347 $\mathrm{mm} /$ bulan dengan rata-rata hari hujan sekitar 16 hari. Temperatur udara rata rata 29 derajat celsius. Kecepatan angin rata - rata 2 - $3 \mathrm{knot} /$ jam.Berdasarkan curah hujan kabupaten Maros dibagi atas dua musim yaitu musim hujan pada periode bulan Oktober sampai Maret dan musim kemarau pada bulan April sampai September.Secara umum masyarakat di Kecamatan Simbang dan Tanralili bekerja disektor pertanian, khususnya bidang persawahan.Petani sawah dikecamatan Simbang dan Tanralili rata-rata mengolah lahan sebanyak 4 kali sebelum di tanami padi.Dimana pengolahan pertama menggunakan bajak singkal, pengolahan kedua dan ketiga menggunakan bajak garu, dan pengolahan terakhir sebelum penanaman menggunakan papan yang dipasang pada bajak untuk meratakan permukaan sawah.

Berdasarkan hasil uji laboratorium lahan sawah uji pada kecamatan Simbang memiliki tekstur lempung liat berdebu dengan perbandingan fraksi pasir $11 \%$, debu $53 \%$, dan liat $36 \%$. Sedangkan pada Kecamatan Tanralili memiliki tekstur lempung liat berdebu dengan perbandingan fraksi pasir 4\%, debu $66 \%$, dan liat $30 \%$. Berdasarkan dari hasil uji kadar air tanah pada lahan sawah uji Kecamatan Simbang kandar air tanahnya sebesar 56,7\% sedangkan pada lahan sawah uji Kecamatan Tanralili kadar air tanahnya sebesar $48,6 \%$.

\section{Analisis Perbandingan Luas Penampang Alat dengan Kecepatan Tenggelam Alat}

1. Analisis Perbandingan Luas Penampang Alat dengan Kecepatan Tenggelam Alat Berdasarkan Berat
Uji daya dukung tanah pada lahan sawah siap tanam dengan menggunakan plat besi dengan luas penampang berbeda $\left(50 \mathrm{~cm}^{2}, 120 \mathrm{~cm}^{2}\right.$ dan $\left.150 \mathrm{~cm}^{2}\right)$ dan berat alat yang bervariasi $(1 \mathrm{~kg}, 2 \mathrm{~kg}$, dan $3 \mathrm{~kg}$ ) dapat dilihat bahwa luas penampang alat memiliki hubungan yang sangat erat dengan kecepatan tenggelam dari alat yang digunakan. Perbandingan antara luas penampang alat dengan kecepatan tenggelam alat pada tekstur A dengan tekstur B dapat dilihat dalam gambar yang disajikan dibawah ini:

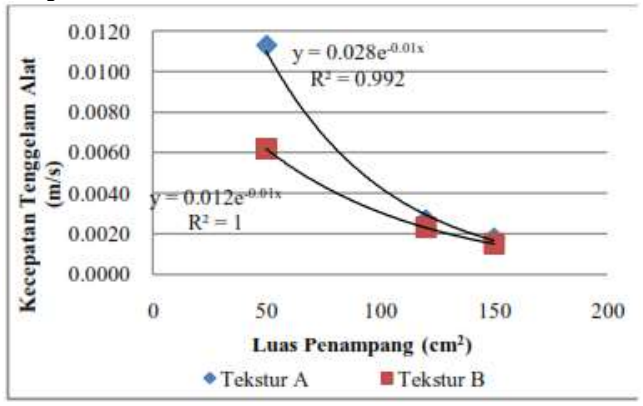

Gambar 2. Grafik hubungan kecepatan tenggelam alat dengan luas penampang untuk berat $1 \mathrm{~kg}$

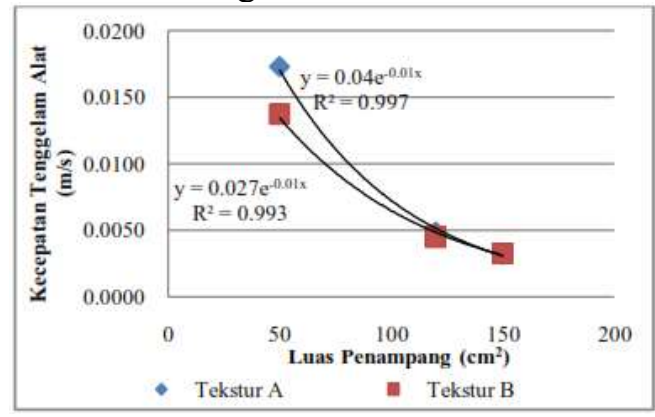

Gambar 3. Grafikhubungan kecepatan tenggelam alat dengan luas penampang untuk berat $2 \mathrm{~kg}$

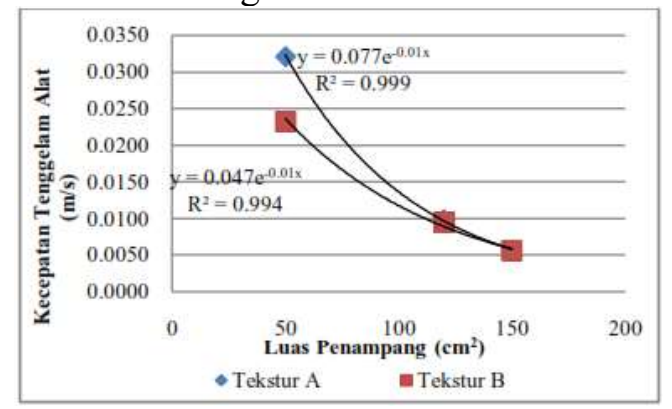

Gambar 4. Grafik hubungan kecepatan tenggelam alat dengan luas penampang untuk berat $3 \mathrm{~kg}$ 
Berdasarkan Gambar 6, hubungan antara kecepatan tenggelam alat dengan luas penampang alat memperlihatkan hubungan yang sangat baik dimana nilai $\mathrm{R}^{2}$ yang didapat adalah 0,9928 dan 1 . Pada Gambar 7 dan Gambar 8 juga menunjukkan hubungan yang sangat erat antara kecepatan tenggelam alat dengan luas penampang alat dimana masingmasing $\mathrm{R}^{2}=0,9974$ dan 0,9932 (Gambar 7) dan gambar $8 \mathrm{R}^{2}=0,9995$ dan 0,9943 . Hal ini didukung oleh pendapat Asdak (2010), yang menyatakan bahwa model persamaan $\mathrm{R}^{2}$ dikatakan baik apabila besarnya mendekati 1 atau sama dengan 1. Gambar 6 , 7, dan 8 juga memperlihatkan bahwa kecepatan tenggelam alat sangat dipengaruhi oleh luas penampang alat. Semakin luas penampang alat yang digunakan maka kecepatan tenggelam alat mengalami perlambatan.

Pengujian daya dukung tanah pada lahan sawah kecamatan Simbang (tekstur A) kecepatan tenggelam alat yang diperoleh lebih besar untuk masing berat alat dibandingkan pengujian daya dukung tanah pada lahan sawah kecamatan Tanralili (tekstur B). Hal tersebut terjadi karena pada tekstur A nilai kadar air tanah dan kandungan fraksi pasirnya lebih besar dibandingkan pada tekstur B. Berdasarkan hasil uji laboratorium nilai kadar air tanah tekstur A sebesar $56,7 \%$ dan kandungan fraksi pasir sebesar $11 \%$ sedangkan pada tekstur A nilai kadar air tanah sebesar 48,4\% dan kandungan fraksi pasir sebesar 4\%. Hal ini sesuai dengan pendapat Kurniaet al (2006), yang menyatakan bahwa nilai tahanan atau dukung tanah meningkat dengan menurunnya kelembapan tanah dan tekstur tanah. Pada kelembapan tanah rendah, daya sanggah atau dukung tanah meningkat, demikian juga dengan meningkatnya kandungan pasir. ketahanan penetrasi meningkat seiring dengan meningkatnya kepadatan tanah.
2. Analisis Hubungan Luas Penampang Alat Dengan Kecepatan Tenggelam Alat Berdasarkan Berat

Analisis hubungan luas penampang alat dengan kecepatan tenggelam alat pada berat $1 \mathrm{~kg}, 2 \mathrm{~kg}$, dan $3 \mathrm{~kg}$ dapat dapat dilihat pada Gambar yang disajikan dibawah ini :

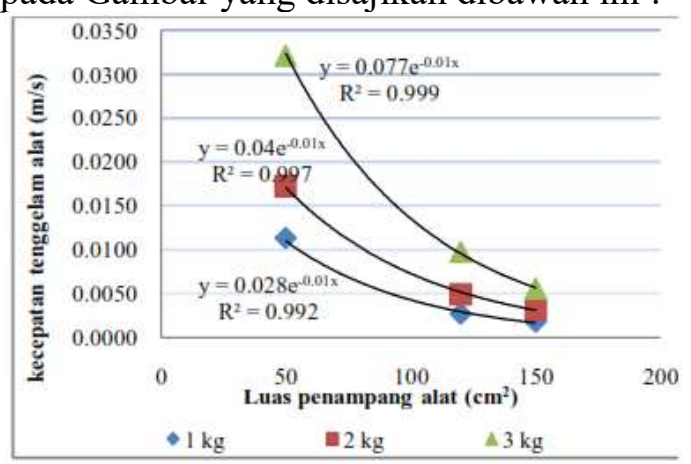

Gambar 5. Grafik hubungan kecepatan tenggelam alat dengan luas penampang alat pada tekstur A

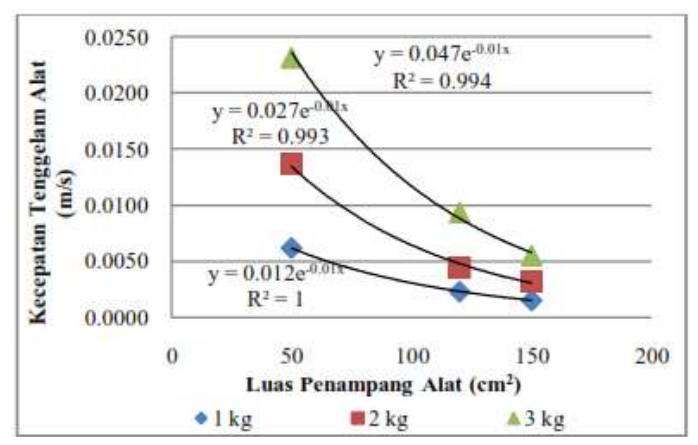

Gambar 6. Grafik hubungan kecepatan tenggelam alat dengan luas penampang alat pada tekstur B

Berdasarkan Gambar 6 dapat dilihat bahwa nilai $\mathrm{R}^{2}$ yang tebentuk masingmasing 0,9995 $(1 \mathrm{~kg}), 0,9974(2 \mathrm{~kg})$, dan $0,9928(3 \mathrm{~kg})$, ini menunjukkan bahwa lineariatas yang terbentuk sangat baik dan menunjukkan hubungan yang sangat erat karena nilai $\mathrm{R}^{2}$ yang terbentuk mendekati 1. Dari Gambar 9 juga dapat dilihat bahwa garis linear yang terbentuk memiliki pola yang sama baik itu untuk garis $1 \mathrm{~kg}, 2 \mathrm{~kg}$, dan $3 \mathrm{~kg}$. hal ini menunjukkan bahwa pada berat alat uji $1 \mathrm{~kg}$ dengan luas penampang $50 \mathrm{~cm}^{2}$ waktu yang dibutuhkan untuk melakukan penetrasi kedalam tanah lebih cepat dan jarak kedalaman yang dicapai 
lebih dalam dibandingkan dengan luas penampang $120 \mathrm{~cm}^{2}$ dan $150 \mathrm{~cm}^{2}$. Ini menunjukkan bahwa semakin luas penampang alat yang digunakan maka kecepatan tenggelam akan menurun dan kedalaman tenggelam alat juga akan berkurang akibat dari besarnya luas bidang tekan sehingga mengurangi daya tekan atau ground pressure dari alat uji.

\section{Analisis Perbandingan Berat Alat dengan Kecepatan Tenggelam Alat Berdasarkan Luas Penampang}

Perbandingan berat alat dengan kecepatan tenggelam alat antara lahan sawah dapat dilihat pada Gambar yang disajikan dibawah ini:

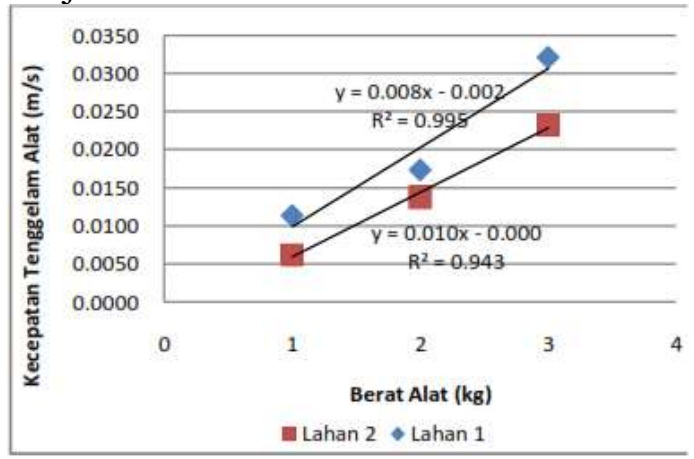

Gambar 7. Grafik hubungan kecepatan tenggelam alat dengan berat alat untuk luas penampang $50 \mathrm{~cm}^{2}$

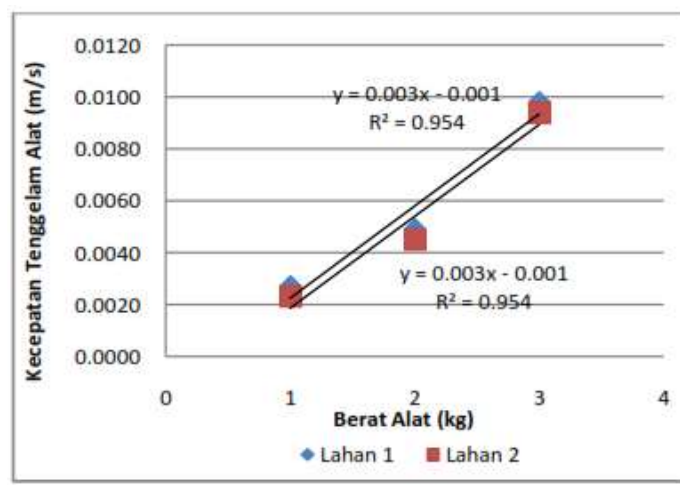

Gambar 8. Grafik hubungan kecepatan tenggelam alat dengan berat alat untuk luas penampang $120 \mathrm{~cm}^{2}$

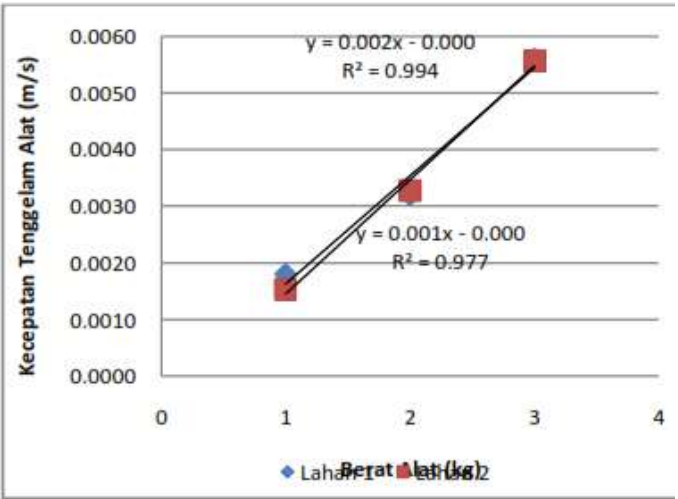

Gambar 9. Grafik hubungan kecepatan tenggelam alat dengan berat alat untuk luas penampang $150 \mathrm{~cm}^{2}$

Berdasarkan Gambar 7 dapat dilihat bahwa hubungan berat alat dengan kecepatan tenggelam alat memiliki hubungan yang sangat erat dimana nilai $\mathrm{R}^{2}$ lahan 1 yang ditampilkan adalah $=0,9437$ dan lahan $2 \mathrm{R}^{2}=0,9959$, ini menunjukkan bahwa semakin berat alat yang digunakan maka kecepatan tenggelam alat akan semakin tinggi dan kemampuan alat untuk melakukana penetrasi kedalam tanah akan semakin besar dan cepat pada kedalaman tertentu (dalam hal ini pengaruh nilai kadar air tanah dan nilai tekstur tanah tidak diabaikan). Gambar 8 dan 9 juga menunjukkan hal yang sama dengan gambar 7 dimana berat alat memiliki hubungan yang sangat erat dengan kecepatan tenggelam.

Berdasarkan gambar 7, 8, dan 9 dapat dilihat bahwa semakin berat alat uji yang digunakan maka kecepatan tenggelam dan kemampuang penetrasi alat kedalam tanah akan mengalami peningkatan dan pada gambar juga dapat dilihat semakin ringan alat uji yang digunakan dan semakin luas penampag alat uji yang digunakan maka kemampuan alat untuk melakukan penetrasi kedalam tanah semakin berkurang (mengalami perlambatan). hal ini di dukung oleh pendapat Kurnia (2006) yang menyatakan bahwa apabila suatu alat berada di atas tanah, maka alat tersebut akan memberikan ground pressure, sedangkan perlawanan yang diberikan 
tanah adalah daya dukung. Jika ground pressure alat lebih besar dari daya dukung tanah, maka alat tersebut akan terbenam.

\section{Analisis Hubungan Luas Penampang Alat, Berat Alat, Dengan Kecepatan Tenggelam Alat}

Pada pengujian daya dukung tanah dilahan sawah siap tanam dilakukan pegujian dengan berat alat yang berbeda. Hal ini dilakukan untuk melihat pengaruh penambahan beban terhadap kemampuan penetrasi alat kedalam tanah. Hubungan luas penampang alat, berat alat, dengan kecepatan tenggelam alat dalam analisis hubungan luas penampang alat, berat alat, dengan kecepatan tenggelam alat dapat dilihat pada gambar dibawah ini:

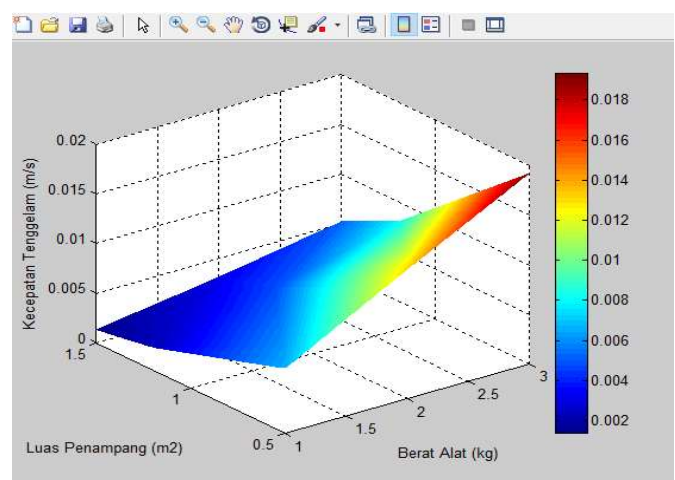

Gambar 10. Grafik hubungan kecepatan tenggelam alat, berat alat, dan luas penampang alat segmen A pada tekstur A

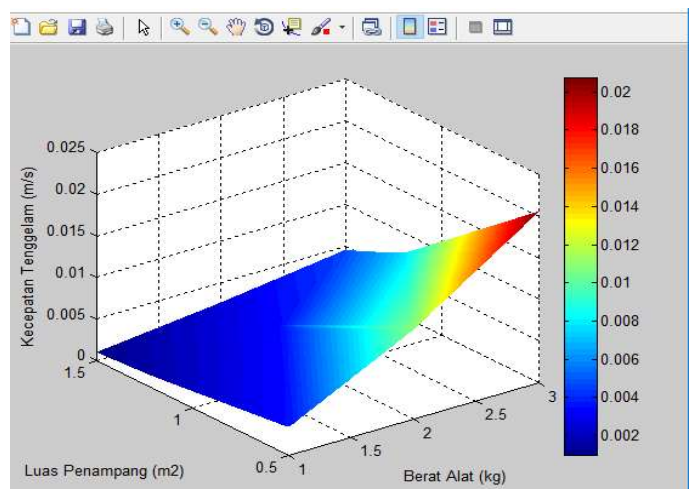

Gambar 11. Grafik hubungan kecepatan tenggelam alat, berat alat, dan luas penampang alat segmen B pada tekstur A

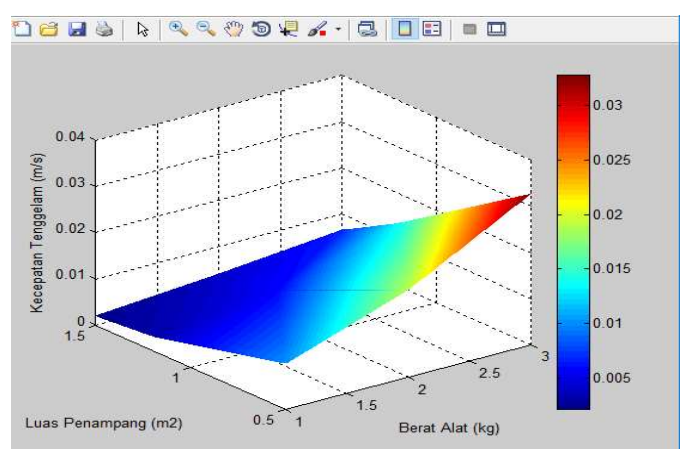

Gambar 12. Grafik hubungan kecepatan tenggelam alat, berat alat, dan luas penampang alat segmen $\mathrm{C}$ pada tekstur $\mathrm{A}$

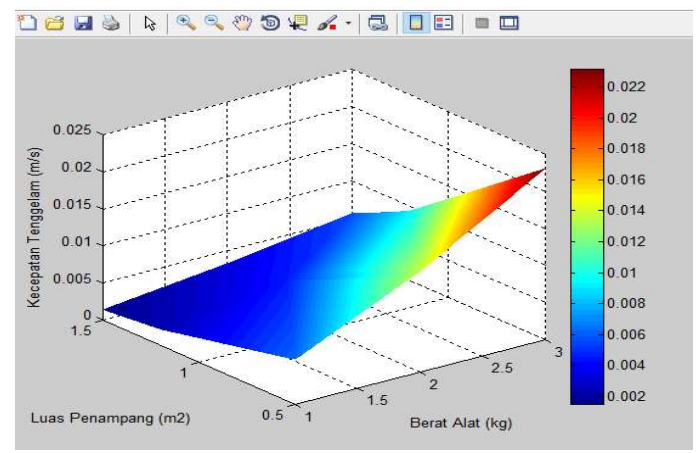

Gambar 13. Grafik hubungan kecepatan tenggelam alat, berat alat, dan luas penampang alat (nilai rata-rata) pada tekstur A

Berdasarkan Gambar 14, 15, 16, dan 17 dapat dilihat bahwa semakin berat alat dan semakin kecil luas penampang maka kecepatan tenggelam semakin tinggi. Hal itu bisa dilihat dari warna grafik yang terbentuk pada grafik surf 3D pada masingmasing gambar. Pada Gambar 14 puncak grafik (band warna merah) menunjukkan, pada berat alat $3 \mathrm{~kg}$ dengan luas penampang $50 \mathrm{~cm}^{2}$, kecepatan tenggelam yang terbentuk adalah lebih tinggi $(0,0193 \mathrm{~m} / \mathrm{s})$ dibandingkan kecepatan tenggelam alat yang terbentukpada luas penampang 120 $\mathrm{cm}^{2}(0,0080 \mathrm{~m} / \mathrm{s})$ dan luas penampang 150 $\mathrm{cm}^{2}(0,0052 \mathrm{~m} / \mathrm{s})$. Hal tersebut berlaku sama untuk berat masing-masing $1 \mathrm{~kg}$ dan $2 \mathrm{~kg}$ untuk luas penampang yang sama (50 $\mathrm{cm}^{2}, 120 \mathrm{~cm}^{2}$, dan $150 \mathrm{~cm}^{2}$ ) pada Gambar 17.

Gambar 14, 15, dan 16 juga menunjukkan hal yang sama dengan 
Gambar 17, dimana kecepatan tenggelam yang terbentuk lebih tinggi pada luas penampang $50 \mathrm{~cm}^{2}$ dengan berat berturutturut $1 \mathrm{~kg}, 2 \mathrm{~kg}$, dan $3 \mathrm{~kg}$ dibandingkan luas penampang $120 \mathrm{~cm}^{2}$ dan luas penampang $150 \mathrm{~cm}^{2}$. Hal ini mununjukkan semakin berat alat dan semakin kecil luas penampang alat, maka kecepatan tenggelam alat semakin tinggi.

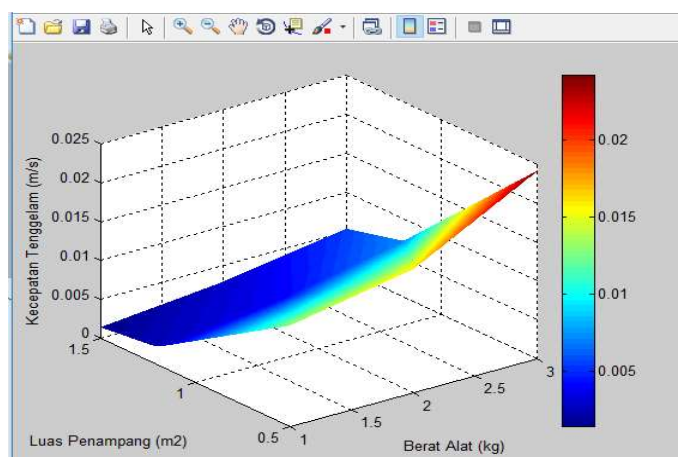

Gambar 14. Grafik hubungan kecepatan tenggelam alat, berat alat, dan luas penampang alat segmen A pada tekstur B

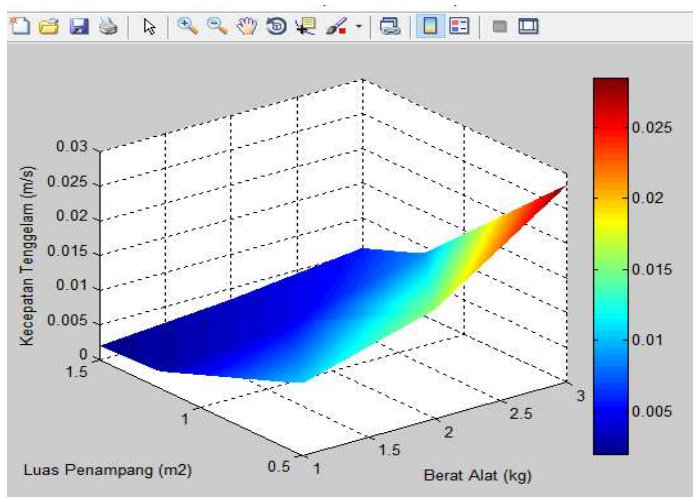

Gambar 15. Grafik hubungan kecepatan tenggelam alat, berat alat, dan luas penampang alat segmen B pada tekstur B

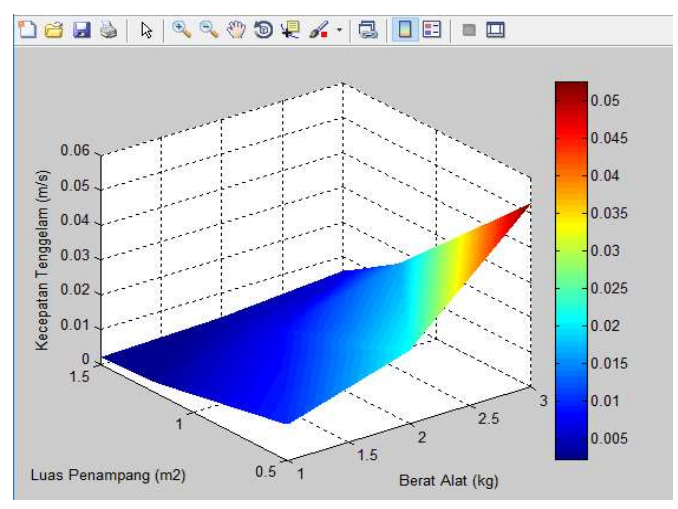

Gambar 16. Grafik hubungan kecepatan tenggelam alat, berat alat, dan luas penampang alat segmen $\mathrm{C}$ pada tekstur $\mathrm{B}$

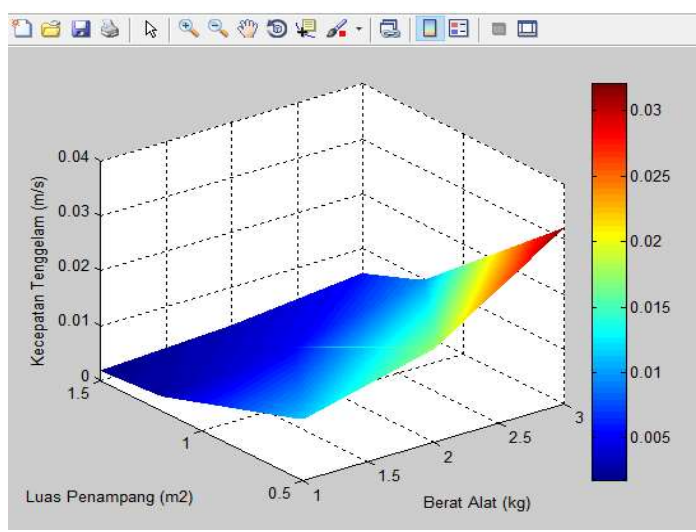

Gambar 17. Grafik hubungan kecepatan tenggelam alat, berat alat, dan luas penampang alat (nilai rata-rata) pada tekstur B

Gambar 18, 19, 20, dan 21 (lahan 2) menunjukkan kondisi yang sama dengan lahan 1 dimana Grafik surf 3D yang terbentuk tidak jauh berbeda. Hal itu bisa dilihat dari band merah pada grafik surf 3D semakin berat plat pembeban yang digunakan dan semakin sempit luas penampang alat maka kecepatan tenggelam dari alat semakin tinggi. Hal demikian berlaku sebaliknya, semakin luas penampang alat dan semakin berkurang (ringan) berat alat maka kecepatan tenggelam alat semakin berkurang (menurun). 


\section{Analisis Hubungan Daya Dukung Tanah dengan Berat Alat}

Kandungan air tanah atau kadar air tanah adalah perbandingan antara berat air yang terkandung dalam tanah dengan berat tanah tersebut yang dinyatakan dalam persen. Jumlah air yang dapat ditahan oleh tanah dapat dinyatakan atas dasar berat atau isi. Pada dasarnya semakin tinggi (\%) kandungan air dalam tanah maka daya sanggah tanah akan semakin menurun sehingga menyebabkan menurunnya kemampuan tanah dalam menopang beban yang berada diatasnya.

Berdasarkan Gambar 22, 23, dan 24 dapat dilihat bahwa nilai daya dukung tanah meningkat seiring bertambah beratnya alat uji yang digunakan. Jika dibandingkan dengan lahan 2, nilai daya dukung tanah lahan 1 lebih rendah karena kadar air pada lahan 2 lebih tinggi dan jumlah fraksi pasir pada lahan 2 lebih besar dibandingkan lahan 1. Hal tersebut dibuktikan berdasarkan hasil uji kandungan air tanah dan tekstur tanah di laboratorium. Hal ini sesuai dengan pendapat Kurniaet al (2006), yang menyatakan bahwa nilai daya sanggah atau dukung tanah meningkat seiring dengan menurunnya kelembapan atau kadar air tanah tanah dan tekstur tanah. Pada kelembapan tanah rendah, daya dukung tanah akan meningkat. Ketika kandungan air tanah meningkat, ketahanan penetrasi tanah menurun.

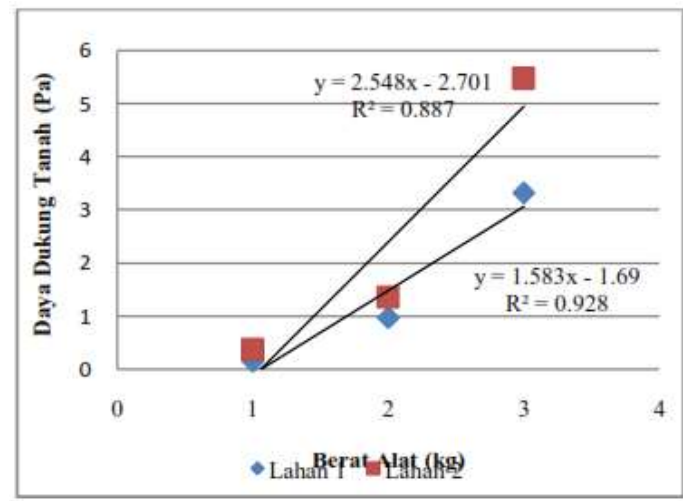

Gambar 18. Grafik hubungan daya dukung tanah dengan berat alat untuk luas penampang $50 \mathrm{~cm}^{2}$

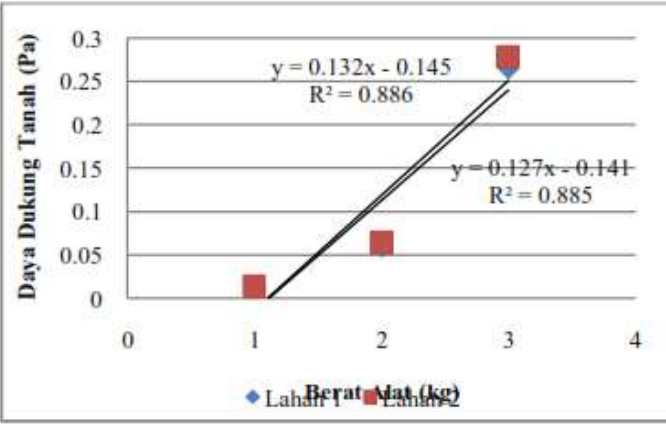

Gambar 19. Grafik hubungan daya dukung tanah dengan berat alat untuk luas penampang $120 \mathrm{~cm}^{2}$

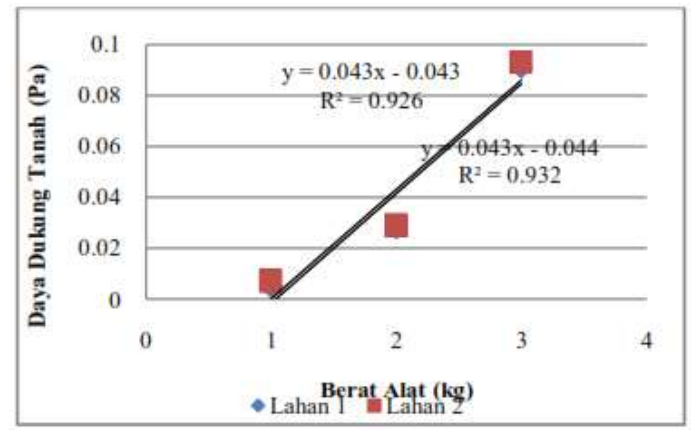

Gambar 20. Grafik hubungan daya dukung tanah dengan berat alat untuk luas penampang $150 \mathrm{~cm}^{2}$

Tingginya kandungan air tanah didalam tanah dipengaruhi oleh banyak dan besarnya pori pada tanah. Pada tanah yang memiliki kandungan liat yang tinggi akan menurunkan kadar air didalam tanah dan secara otomatis akan meningkatkan nilai daya dukung pada tanah.

\section{Analisis hubungan daya dukung tanah dengan luas penampang alat}

1. Analisis Perbandingan Daya Dukung Tanah dengan Luas Penampang Alat Berdasarkan Berat

Pengujian daya dukung tanah di dua lokasi berbeda yaitu di Kecamatan Simbangdan Kecamatan Tanralili dilakukan untuk mengetahui seberapa dalam alat uji tenggelam kedalam tanah sawah dengan penambahan beban pada alat uji sehingga alat uji memiliki berat 1 $\mathrm{kg}, 2 \mathrm{~kg}$, dan $3 \mathrm{~kg}$. Penambahan berat tersebut dimaksudkan untuk melihat 
pengaruh dari penambahan barat alat terhadap luas bidang tekan dan kemampuan lahan atau tanah untuk menahan beban yang berada diatasnya.

Analisis hubungan daya dukung tanah dengan luas penampang alat dapat dilihat pada gambar yang disajikan dibawah ini:

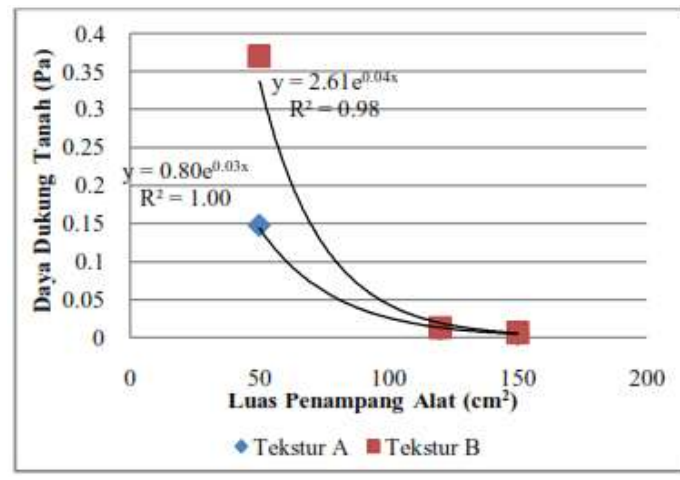

Gambar 21. Grafik hubungan daya dukung tanah dengan luas penampang alat untuk berat alat $1 \mathrm{~kg}$

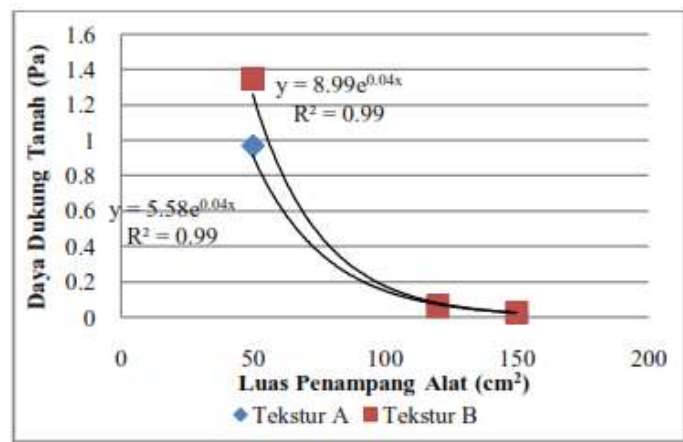

Gambar 22. Grafik hubungan daya dukung tanah dengan luas penampang alat untuk berat alat $2 \mathrm{~kg}$

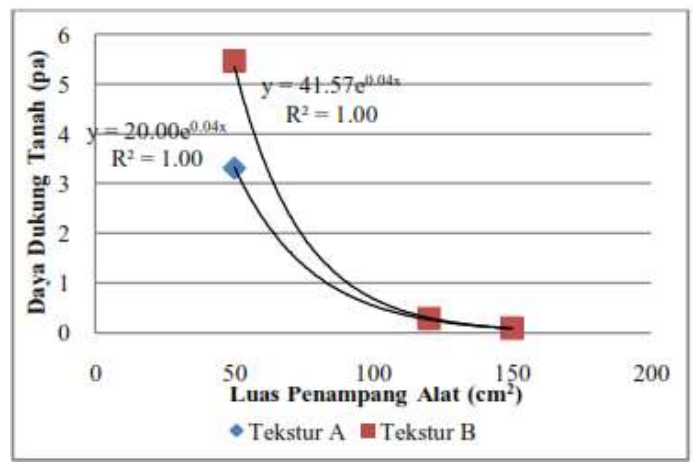

Gambar 23. Grafik hubungan daya dukung tanah dengan luas penampang alat untuk berat alat $3 \mathrm{~kg}$
Berdasarkan Gambar 25, 26, dan 27 dapat dilihat bahwa luas penampang sangat berpengaruh terhadap nilai daya dukung tanah. Dimana nilai daya dukung tanah meningkat jika luas penampang alat yang digunakan semakin sempit. Hal ini terjadi karena semakin luas bidang tekan pada permukaan maka daya apung benda semakin besar dan kemampuan menopang tanah semakin besar.

Besarnya nilai daya dukung tanah juga sangat dipengaruhi oleh kandungan air tanah dan jumlah fraksi pasir dalam tekstur tanah. Hal itu dapat dilihat dari grafik yang terbentuk, dimana jika dibandingkan antara lahan 1 dengan lahan 2 nilai daya dukung tanah lebih besar pada lahan 2 dibandingkan lahan 1. Pada kadar air tanah $56,7 \%$ dan fraksi pasir $11 \%$ nilai daya dukung tanah sebesar $3,315 \mathrm{~Pa}$, sedangkan pada kadar air tanah 48,4\% dan fraksi pasir 4\% nilai daya dukung tanah sebesar 5,466 Pa.

2. Analisis Hubungan Daya Dukung Tanah dengan Luas Penampang Alat Berdasarkan Berat

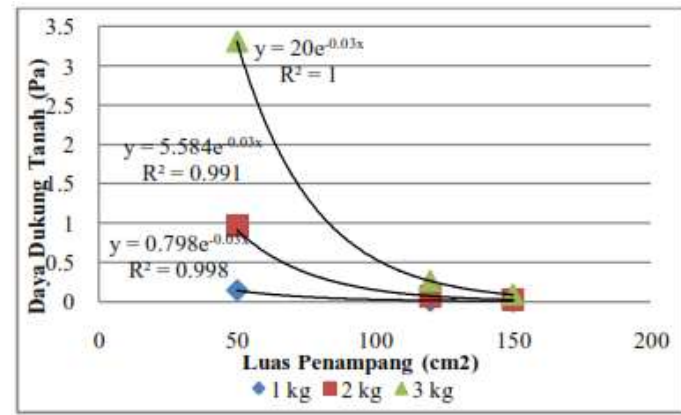

Gambar 24. Grafik hubungan daya dukung tanah dengan kecepatan luas penampang alat padatekstur $\mathrm{A}$ 


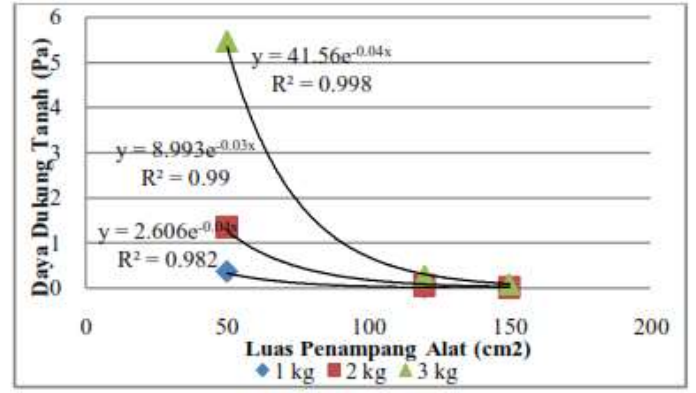

Gambar 25. Grafik hubungan daya dukung tanah dengan kecepatan luas penampang alat padatekstur B

Berdasarkan Gambar 28 dan 29 dapat dilihat bahwa pada luas penampang $150 \mathrm{~cm}^{2}$ grafik untuk berat $1 \mathrm{~kg}, 2 \mathrm{~kg}$, dan $3 \mathrm{~kg}$ menuju satu titik dan akan saling berpotongan. Hal tersebut menandakan bahwa pada luas penampang 150 berat alat tidak lagi dapat mempengaruhi kedalaman tenggelam alat, akibat dari luasnya bidang tekan dan daya dukung tanah. Hal ini bisa dibandingkan dengan luas penampang 120 $\mathrm{cm}^{2}$ dan $50 \mathrm{~cm}^{2}$ dimana grafik yang terbentuk saling berjauhan akibat dari nilai daya dukung tanah yang terbentuk semakin besar.

\section{Analisis Hubungan Berat Alat, Luas Penampang, dengan Waktu Tenggelam Alat}

Analisis hubungan berat alat, luas penampang, dengan waktu tenggelam alat pada uji daya sanggah tanah pada lahan sawah siap tanah dapat dilihat dari gambar yang disajikan dibawah ini:

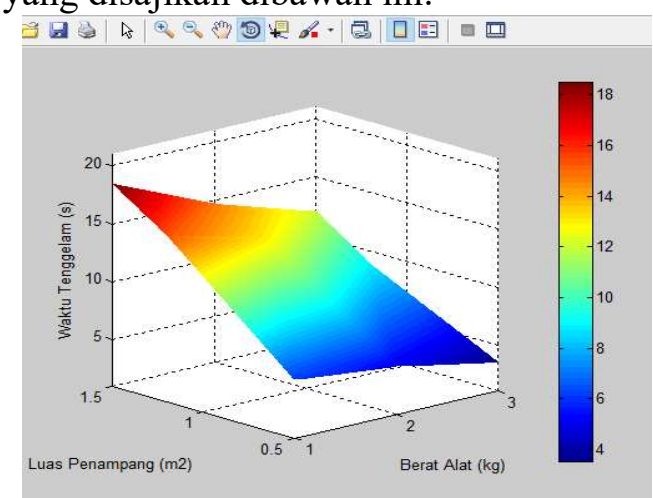

Gambar 26. Hubungan berat alat, luas penampang alat, dengan waktu tenggelam alat padatekstur $\mathrm{A}$
Berdasarkan Gambar 30 dapat dilihat bahwa pada berat alat $3 \mathrm{~kg}$ dengan luas penampang alat $50 \mathrm{~cm}^{2}$ waktu yang dibutuhkan alat uji plat pembeban untuk melakukan penetrasi ke dalam tanah adalah 3,53 detik. Sedangkan pada luas penampang $120 \mathrm{~cm}^{2}$ dan $150 \mathrm{~cm}^{2}$ dengan berat alat yang sama $(3 \mathrm{~kg})$ waktu yang dibutuhkan alat uji plat pembeban untuk melakukan penetrasi kedalam tanah adalah 8,85 detik dan 12,03 detik. Hal ini menunjukkan bahwa semakin sempit luas penampang alatuji yang digunakan maka waktu yang dibutuhkan alat untuk melakukan penetrasi kedalam tanah semakin cepat.

Gambar 30 juga menunjukkan pengaruh dari penambahan beban, dimana semakin berat dan semakin sempit luas penampang alat uji yang digunakan maka waktu yang dibutuhkan untuk melakukan penetrasi kedalam tanah semakin cepat.

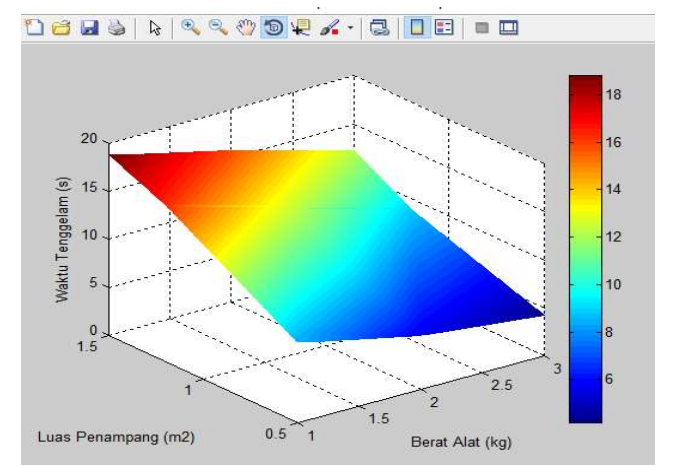

Gambar 27. Hubungan berat alat, luas penampang alat, dengan waktu tenggelam alat pada tekstur B

Pada lahan sawah kecamatan Tanralili (Gambar 31) menunjukkan hubungan korelasi yang sama dengan lahan sawah kecamatan simbang dimana grafik surf 3D yang terbentuk tidak jauh berbeda. Hal itu dapat dilihat dari band merah pada surf 3D semakin berat alat adan semakin sempit luas penampang alat uji yang digunakan maka waktu yang dibutuhkan alat uji untuk melakukan penetrasi kedalam tanah semakin cepat. Begitupun sebaliknya, semakin luas 
penampang alat dan semakin ringan alat uji yang digunakan maka waktu yang butuhkan alat untuk melakukan penetrasi kedalam tanah akan semakin lama. Hal ini disebabkan berkurangnya daya tekan (akibat dari pengurangan beban pada alat uji) dan semakin besarnya daya apung (floatation) dari alat uji yang digunakan.

\section{Analisis Hubungan Berat Alat, Luas Penampang Alat, dengan Persentase Tenggelam Alat}

Pada uji daya dukung tanah pada lahan sawah siap tanam di kecamatan Simbang dan kecamatan Tanralili juga dilakukan pengukuran kedalaman pelumpuran dengan menggunakan mistar ukur. Data pengukuran kedalaman pelumpuran pada lahan tersebut digunakan untuk menghitung persentase kedalaman tenggelam alat uji terhadap kedalaman pelumpuran. Analisis hubungan berat alat, luas penampang alat dengan persentase tenggelam alat pada uji daya sanggah tanah pada lahan sawah siap tanah dapat dilihat dari Gambar yang disajikan dibawah ini:

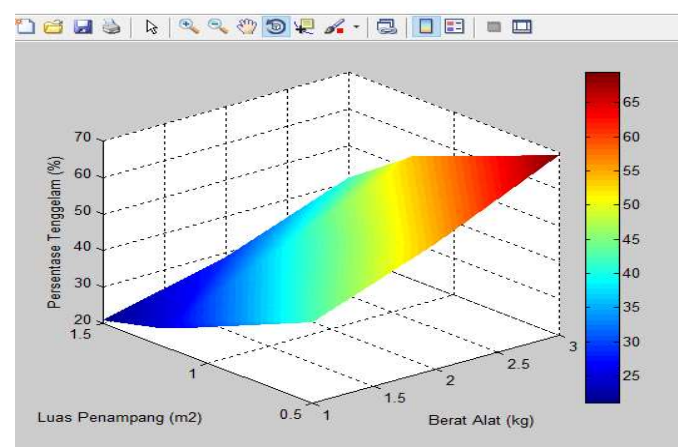

Gambar 28. Hubungan kecepatan tenggelam alat, berat alat, dengan Persentase tenggelampada tekstur A

Pada Gambar 32 dapat dilihat bahwa persentase kedalaman tenggelam alat semakin meningkat seiring dengan bertambah sempitnya luas penampang alat dan bertambah beratnya alat uji yang digunakan. Hal ini disebabkan oleh semakin sempitnya luas bidang tekan dan penambahan berat pembeban pada alat uji yang digunakan sehingga ground pressure alat lebihbesar dibandingkan daya dukung atau sanggah yang diberikan oleh tanah yang mengakibatkan alat terbenam kedalam tanah.

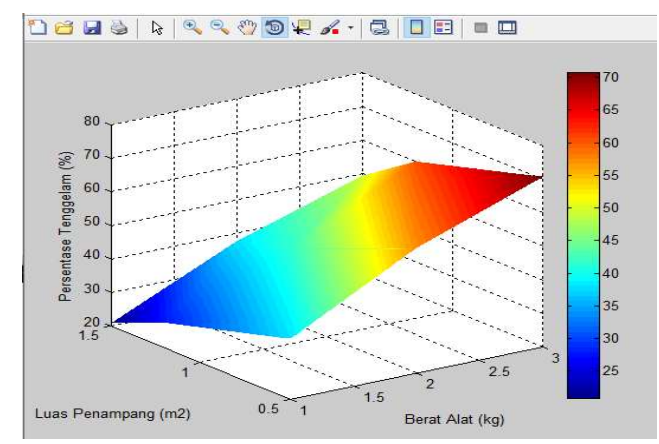

Gambar 29. Hubungan kecepatan tenggelam alat, berat alat, dengan Persentase tenggelam Alat pada tekstur B

Berdasarakan Gambar 33 untuk tekstur A dapat dilihat bahwa persentase tenggelam alat paling tinggi sebesar $70,8 \%$ pada berat alat uji sebesar $3 \mathrm{~kg}$ dengan luas penampang $5 \mathrm{~cm}^{2}$ (band merah tua pada grafik surf 3D) dan persentase tenggelam alat terendahnya adalah sebesar 20,9\% pada berat alat $1 \mathrm{~kg}$ dengan luas penampang $150 \mathrm{~cm}^{2}$ (band biru tua pada grafik surf 3D). Semakin berat alat uji yang digunakan dan semakin sempit luas penampangnya maka persentase tenggelam alat akan semakin besar.

Persentase tenggelam alat terhadap kedalaman pengukuran menggunakan mistar ukur untuk tekstur B terlihat lebih tinggi (20,9\%-70,8\%) jika dibandingkan dengan persentase tenggelam alat pada tekstur A (21,1\%-69,5\%). Pada tekstur A menunjukkan hasil pengukuran waktu tenggelam dan kedalaman tenggelam lebih besar dibandingkan pada tekstur B. Hal itu terjadi karena hasil bagi dari perhitungan persentase kedalaman tenggelam alat terhadap pengukuran kedalaman rata-rata pelumpuran lahan sawah menggunakan mistar ukur pada tekstur B adalah sebesar $13,7 \mathrm{~cm}$ sedangkan pada tekstur A rata-rata kedalamannya adalah $16,3 \mathrm{~cm}$, sehingga persentase yang tampak pada grafik surf 
3D Gambar 33 lebih tinggi dibandingkan grafik surf 3D gambar 32.

Perbedaan kedalaman dan waktu tenggelam alat antara tekstur A dengan tekstur B ini disebabkan oleh kadar air tanah dan tekstur tanah. Kadar air pada tekstur A 56,7 \% dan tekstur B 48,4\%. Kandungan fraksi pasir padatekstur A 11\% dan tekstur B 4\%. Hal ini sesuai dengan pendapat Kurniaet al (2006), yang menyatakan bahwa nilai daya dukung tanah meningkat dengan menurunnya kelembapan tanah dan tekstur tanah. Pada kelembapan tanah rendah, daya dukung tanah meningkat, demikian juga dengan meningkatnya kandungan pasir. Ketahanan penetrasiakan meningkat seiring dengan meningkatnya kepadatan tanah.

\section{PENUTUP}

\section{Kesimpulan}

Kesimpulan dari penelitian uji daya dukung tanah pada lahan sawah siap tanam adalah sebagai berikut:

1. Daya dukung tanah dipengaruhi oleh kadar air tanah, fraksi pasir, luas penampang alat, dan bobot pemberat.

2. Daya dukung tanah (y) untuk kadar air $56,7 \%$ dan fraksi pasir $11 \%$ dengan luas penampang alat (x) menghasilkan rumusy $=41,57 \mathrm{e}^{0,04 x}$ dan daya dukung tanah (y) untuk kadar air 48,6\% dan fraksi pasir $4 \%$ dengan luas penampang alat (x) menghasilkan rumus $\mathrm{y}=$ $20,00 \mathrm{e}^{0,04 \mathrm{x}}$

3. Daya dukung tanah (y) untuk kadar air $56,7 \%$ dan fraksi pasir $11 \%$ dengan bobot pemberat (x) menghasilkan rumusy $=1,390 \mathrm{x}$ dan Daya dukung tanah (y) untuk kadar air 48,6 \% dan fraksi pasir $4 \%$ dengan bobot pemberat (x) menghasilkan rumusy $=0,8592 x$.

\section{Saran}

Pengambilan sampel data perpetak sawah sebaiknya diperbanyak agar tingkat akurasi nilai daya dukung tanah yang diperoleh semakin tinggi dan setiap kali pengambilan data atau berpindah tempat dalam satu petak sawah usahakan mengambil sampel tanah untuk pengujian kadar air dan tekstur tanah.

\section{DAFTAR PUSTAKA}

Agus Fahmuddin, Abdurachman, Sarwono, Achmad, dan Wiwik, 2004. Tanah Sawah dan Teknologi Pengelolaannya. Pusat Penelitian dan Pengembangan Tanah dan Agroklimat Departemen Pertanian: Jakarta.

Asdak, C. 2010. Hidrologi dan Pengelolaan Daerah Sungai. Gadjah Mada University Press: Yogyakarta.

BPS Kabupaten Maros. 2013. Kabupaten Maros Dalam Angka. Seksi Integrasi Pengolahan Data dan Deseminasi statistik. Maros.

Badan Pusat Statistik. 2014. Statistik Lahan Pertanian Tahun 2009-2013. Pusat Data dan Sistem Informasi Sekretariat Jendral-Kementrian Pertanian: Jakarta.

Fadli. 2012. Analisis Regresi. Universitas Sumatra Utara: Medan.

Hanafiah, Kemas Ali. 2009. Dasar-Dasar Ilmu Tanah. PT. Raja Grafindo Persada: Jakarta.

Islami, T. dan Utomo, W. H., 1995. Hubungan Tanah, Air dan Tanaman. IKIP Semarang Pres: Semarang.

Kurnia, Undang.M. Sodik dan Setiari, 2006. Sifat Fisik Tanah dan Metode Analisisnya. Balai Besar Litbang Sumberdaya Lahan Pertanian Departemen Pertanian: Jakarta. 